\title{
The Research and Practice on Innovative Ability of Non-computer Professional Computer College Students
}

\author{
Han Zhiying \\ Jilin Huaqiao University of Foreign Languages \\ Changchun 130117, China
}

\begin{abstract}
In the information age, computer education is basic platform to cultivate college students' innovation ability and comprehensive practical ability. The cultivation of the innovative ability of non-computer majors has become an important content of basic computer education in colleges and universities. Fully combining with teaching practice, this paper deeply analyzed innovative ability of the non-computer college students in the field of information and gave effective strategy, thus providing the reference for the construction of college computer training.
\end{abstract}

Keywords-Computer; Innovation ability cultivation; Noncomputer professional college students

\section{INTRODUCTION}

With today's economic and social development in our country a large number of innovative and bold innovation is urgently needed. And innovation becomes the subject of the era Cultivating students' innovation ability in college computer education has become an important strategic task. Computer innovation ability functions as the measure of students' comprehensive quality and professional ability. It is an important subject that computering teachers are now confronted with to grope for a series of suitable training strategy through practice to improve the students' innovation ability in the use of information technology to solve the problem of flexibility, independence, creativity, and at the same time stimulate students innovation consciousness and innovation spirit in the social practice,

\section{THE MAIN PROBLEM AT PRESENT}

Higher education is experiencing a great change of social development based on innovation. computer basic education innovation education in Chinese universities still has some deficiencies: computer education in colleges and universities can not completely get rid of the bondage of exam-oriented education, the teaching content updates lag behind the demand of social and economic development; the condition of the college students enrolled in computer application level is uneven, unable to realize their aptitude to hierarchical teaching. Computer teaching of non-computer professional failed to make scientific innovation in the professional field applications and services; The construction of practice teaching system needs the goal. Students use the Internet for individual autonomous learning and lack the independent innovation ability. Evaluation system is not perfect; the single evaluation method can't motivate students enthusiasm of innovation.

\section{BASED ON THE TEACHING MODE REFORM OF CULTIVATING THE ABILITY OF INNOVATION}

\section{A. Innovate hierarchical teaching according to the students computer application ability}

College students' computer application level is different, so learning demand is different. If the differences of objective existence are not considered, it will make student lack of learning motivation and innovation power. To solve the problems, the team the hierarchical teaching in the university computer basic course, the student enrollment, unified entrance computer operation level grading test, mastered student achievement raw data, thus got result, and hierarchical planning reasonably. Entry level test standard of undergraduate are not required to enroll this course; and theses students are regarded as the focus of the innovation work object, specially equipped with teachers for them in order to meet the requirements of undergraduate degree; Students that do not meet the undergraduate degree standard computer level are also different, in view of the "layer" in the same class difficult problems, teachers design a different difficulty level of practice, case is divided into "foundation, validation, comprehensive and design type" case, the students can selectively progressive practice, according to their aptitude, to make them meet the needs of computer education.

Team carried out graded teaching and more than 2300 students in the learning process tracked, including the entrance computer level test, the final exam, and the national college students' computer office automation level exam results are analyzed (see below). USES hierarchical teaching method, compared with the admission test, students' final grade and secondary test scores improved, excellence rate reached $31.5 \%$ and $31.5 \%$ respectively, the pass rate of $90 \%$ or more, office automation level exam grade point average of 84.59 , a leading position in the Jilin province colleges and universities. Born at the same time, there are three undergraduate degrees after cultivating the college students in Jilin province won first prize in the computer design competition and second prize of 
excellent result, works of creative judges receive consistent affirmation, hierarchical teaching effect is remarkable.

TABLE I. THREE PHASE COMPUTER TEST RESUlt ANALYSIS

\begin{tabular}{|c|c|c|c|c|c|}
\hline Test name & Average & Highest score & Lowest score & Excellence rate & Pass rate \\
\hline (1)entrance exam & 24.5 & 72.9 & 2.1 & $0 \%$ & $0.73 \%$ \\
\hline (2)final exam & 76.9 & 99.2 & 13.5 & $31.50 \%$ & $91.60 \%$ \\
\hline (3)grade exam & 84.6 & 99 & 19.3 & $57.50 \%$ & $99.60 \%$ \\
\hline
\end{tabular}

B. To achieve the classification of the innovative teaching according to the different demands of the students' computer application

In order to make the students' computer application in the field match the professional teaching direction, the team did a lot of research and analyzed the market demand, since each major has many graduating students comprehensive skills training courses, such as: office automation training, Excel advanced reporting applications, audio and video processing, graphic design, and other courses, professional innovation laid a solid foundation for graduates; In addition, in some public computer course, the teachers also group students independently and conduct online research, social investigation, let the student collect materials from their respective professional fields, so that students can use this professional material for computer learning, so their learning enthusiasm will be much higher. Thus the different classification of professional teaching can be achieved the same course, students have more innovation and practice platform.

\section{To drive innovation by design}

In The traditional teaching mode, the proportion of the basic and validating experiment is so large, validation experiments, the design thinking and innovation consciousness of students are suppressed.

Innovation teaching approach requires the design work should be the core of the whole teaching process. At the beginning of the study, students formed a cooperation team. Together with the teachers, they took counsel to formulate design goals, constantly apply knowledge to students around the design theme in the design of the independent material, at the end of the course they achieved their design goals, namely to create personalized innovation works.

Design driven teaching method is exploratory. students are selected after the design theme, to achieve the expected design goal, take the initiative to transform knowledge into design results in a timely manner, the design of the design in the whole process not only improves the students ability to innovate, and to cultivate the team cooperation spirit.182 students in two classes are driven by the design innovation of teaching methods to carry out the PS plane graphic design course teaching, under the same inspection standard. Compared with a session of 172 students in the professional, performance excellence rate rises $9.5 \%$, the qualified rate is $8.6 \%$, higher than the previous work output rose $112 \%$, comparing the results below, proved the design driven innovation teaching method the effect is significant.

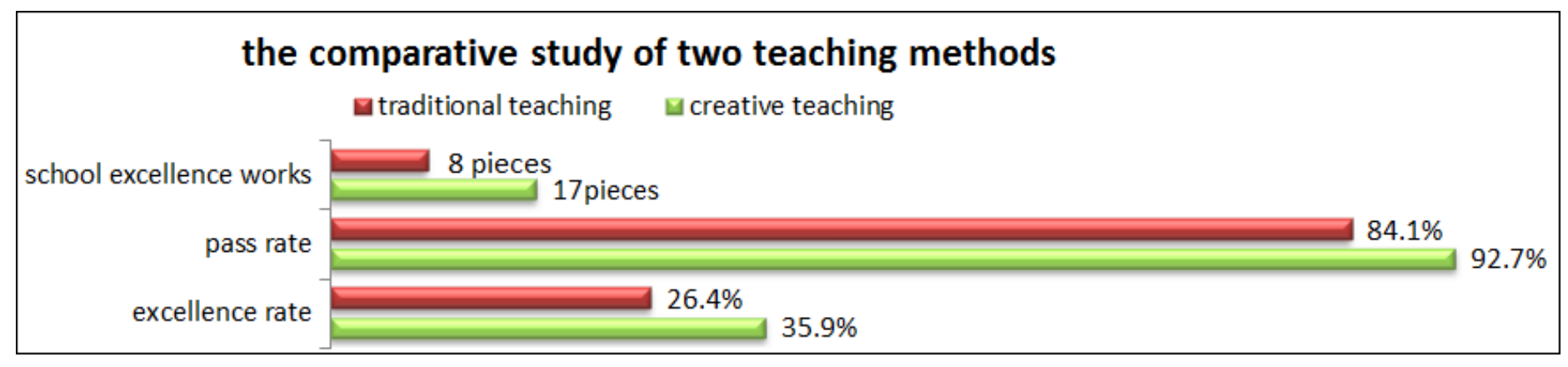

Fig. 1 The comparative study of two teaching methods

\section{Combine the traditional classroom teaching with the} advantage of network information technology teaching

In today's education highly informationization, the network learning resources are more and more increasingly rich. Students become more and more diversified in learning knowledge. Computer teachings stimulate students' creativity and vitality. it needs to combine classroom teaching and network teaching closely, and rely on the network environment. Teachers recommended optimization of network resources for students to choose their learning, and use the network to realize interaction between students and teachers, moderately flip classroom, online and offline mixed teaching. The hybrid teaching mode make students have the innovative development of relatively free space, expand the learning space and time, improve the students' ability of autonomous learning and independent innovation. Research team for the 2016 grade two classes, a total of 105 students adopted online hybrid method to carry out the Excel advanced reporting curriculum teaching, with a level 2015 without adopting mixed method of 111 students. under the same inspection standard, online hybrid method of teaching to improve student performance. 


\section{THE PROCESS OF PERFECTING STUDENTS’ INNOVATIVE ABILITY}

\section{A. Make in-depth research and better teaching materials}

In Information era, the application of the computer almost penetrated into all aspects of society and economy, and the knowledge updating cycle is very short. In order to solve the problem of teaching knowledge relative lag, the team provides students with innovative teaching contents. They make deep research to understand the needs of unit to collect first-hand information industry for teaching and from the cooperation unit, graduates and students intern, network and other ways. The innovation of the teaching content is valid and the freshness of knowledge and students' learning enthusiasm are ensured.

\section{B. Reform of traditional evaluation methods, establish a diversified evaluation mode innovation}

To a large extent Evaluation method affects students' learning attitude and innovation enthusiasm. The traditional examination way takes a small proportion of grades increasing proportion of the final exam method and can't arouse students' interests to motivate. So teachers need to explore a new way of examination to improve the students' comprehensive quality and creative ability by adopting flexible and varied way of evaluation through the innovation consciousness of college students, after-class autonomous learning initiative. Teachers design innovation evaluation and carry on the comprehensive evaluation, especially improve the proportion of design work, creativity, technology innovation, including the works and the diversification of social practice and spent by the evaluation, make diversification assessment of students' innovative power.

\section{Form students' innovative team by uniting many departments}

In addition, computer teaching department select outstanding students not only in the teaching process but also can cooperate with the school TV station, network center, the school and college students' innovative undertaking department and other departments jointly. Tutorial system management is adapted and aimed at to help those outstanding students. Students are encouraged and guided to take an active part in computer design competition, innovation team information class lectures, class students, cooperation between colleges computer design projects and other kinds of activities. In doing so, the students' computer and information technology is closely linked to the career of their own learning and the future. f information technology is used and students' comprehensive practical ability, their employment competitiveness, at the same time are also improved.

\section{CONCLUSION}

Computer education plays a very important role in 1 students' comprehensive ability and innovation ability training in colleges and universities. In order to solve the problems at present, the research team actively research and practice and finally find out the cause of the students lack innovative consciousness and innovative ability. They explore a series of non-computer professional computer college students innovative ability training strategies. The result has proved its help to improve students' innovative drive, and the ability to innovate. Research results have positive significance and have certain promotion value in the colleges and universities.

\section{ACKNOWLEDGEMENT}

This thesis is the periodic study of education research project of computer foundation in colleges and universities nationwide "Research and practice of computer basic practice teaching model based on innovation ability training".

\section{REFERENCES}

[1] Feng Lixia, The development of creativity and innovation [M], Qinghua university press, In August 2013.

[2] The guiding suggestion about enforcing practical teaching ,Education department of Jilin Province, In December 2014.

[3] Ma Bin, The research and explore of three- dimensional computer practical teaching $[\mathrm{J}]$, Laboratory research and exploration, In October 2013.

[4] Ju Shenggen Chen Run . Exploration and practice on the construction of computer innovation practical teaching platform $[\mathrm{J}]$, Experimental technology and management,2017.8. 